\title{
Experience on a Low Cost Way to Obtainal-Ti Ceramic Foams
}

\author{
Joan Antoni Cusidó ${ }^{a}$ Lázaro Vicente Cremades ${ }^{b *}$, Margarita González $^{b}$ \\ ${ }^{a}$ Departament de Física i Enginyeria Nuclear, Universitat Politècnica de Catalunya - UPC, \\ Pere Serra 1-15, 08190, Sant Cugat del Vallès, Barcelona, Spain \\ ${ }^{b}$ Departament de Projectes d'Enginyeria, Escola Tècnica Superior d'Enginyeria Industrial de \\ Barcelona, Universitat Politècnica de Catalunya-UPC, Av. Diagonal 647, 08028, Barcelona, Spain
}

Received: April 23, 2015; Revised: July 8, 2015

\begin{abstract}
An experience on a simple process for producing alumina-rutile-mullite ceramic foams by using aqueous particulate slurries is proposed. The sintering process is achieved in one unique thermal process at $1200^{\circ} \mathrm{C}$ in air. The description of the process, physical properties and morphological studies are reported. Microstructure is studied by using confocal optical microscopic technique. The highly active porous foam structure of this ceramic material produced according to the low-cost process presented here could extend its use in a broad range of applications, such as catalytic, biomedical scaffolds, filtering, etc.
\end{abstract}

Keywords: ceramic foam, replica technique, alumina, rutile, mullite, confocal microscopy

\section{Introduction}

During the last decade the number of applications of porous ceramic materials has been increasing due to their favorable properties such as high temperature stability, high permeability, low mass, low specific heat capacity and low thermal conductivity. Several processing routes using replica, sacrificial templates or direct foaming methods are nowadays available for the production of macroporous ceramics. Three manufacturing routes are usually followed: gel casting, particulate sacrificial fillers, hollow building blocks and reaction bonded-modified polyurethane replica technique as a way to producing cellular ceramics ${ }^{1}$. These routes differ greatly in terms of processing conditions and properties of the resulting microstructure ${ }^{2,3}$.

The polymer replica technique is an easy and well-established method that was patented in $1963^{4}$ to prepare open cellular structures with pores sizes ranging from $200 \mu \mathrm{m}$ to $3 \mathrm{~mm}$ at porosity levels between $40 \%$ and $90 \%$.

Ceramic foam and cellular ceramics have a wide range of applications: gas filters, catalyst supports ${ }^{5,6}$, thermal insulation, refractory materials, biomedical materials for bone implants ${ }^{7}$, high-specific strength materials, high-efficiency combustion burners, etc. Their development speeded up during the eighties of the twentieth century ${ }^{8-10}$ specifically for filtration in metal smelting applications.

The present study describes a simple process for making ceramic foams by using aqueous particulate slurries. It does not use sacrificial blowing agents and/or sacrificial fillers or preceramic polymers. It consists of one single process of sintering at $1200{ }^{\circ} \mathrm{C}$ and represents a simple synthesis route, which is a similar route to those developed by other authors ${ }^{11}$, producing a low cost glass-based binding phase after sintering. Thus, this study aims to describe the production of ceramic foams through the ceramic replication techniquealong with

*e-mail: lazaro.cremades@upc.edu the mechanical, thermal and microstructure characterization of the products obtained.

\section{Experimental Procedure}

Main raw material chosen for the proposed ceramic replication technique was the polyurethane foam of polyester basis and open cell structure. It is a commercial product (Genfiltro, 18-22 pores per inch), elastic, without apparent microporosity, and useful for a number of diverse applications. It comes in the form of parallelepipeds of $2 \mathrm{~m}^{2}$ and $10 \mathrm{~cm}$ thick, with several densities depending on its application (in our case, two types were used: large macropore $\rho=27 \mathrm{~kg} \mathrm{~m}^{-3}$ and small macropore $\rho=30 \mathrm{~kg} \mathrm{~m}^{-3}$ ).

The particulate slurry was prepared with reactive alumina $\left(\mathrm{Al}_{2} \mathrm{O}_{3}\right)$ (from Alcoa, reference CTC-20). Crystallographically it corresponds to $\alpha$-alumina species whose crystals have an average grain size of $1 \mu \mathrm{m}$.

Other main products used were: titanium dioxide $\left(\mathrm{TiO}_{2}\right)$ as rutile (DuPont, ref. R-931), which average grain size was $0.55 \mu \mathrm{m}$; sodium feldspar $\left(\mathrm{NaAlSi}_{3} \mathrm{O}_{8}\right)$ (Llansa S.A., ref. SE); and ball clay (WWB Debon Clays Ltd.) consisting of a mixture of silicates and phyllosilicates with very low particle size and very high plasticity. The addition of ball clay as plasticizer has also been done in ceramic foams of $\mathrm{SiC}$ and other formulationswith success ${ }^{12}$. Other components used but in a smaller proportion were: wheat gluten as binder, boric acid as a fungicide, sodium silicate and sodium carbonate as deflocculants, and sodium aluminate as a thickener.

Rheology and adherence on the polymeric foam of the impregnating suspension are the most crucial points in the ceramic replication technique ${ }^{13}$. In order to achieve the adherence of the ceramic slurry on polyurethane fibers, a pre-treatment was necessary. Up to 5 products in aqueous solution were tested to act as mordant or binder: ethanol, 
acetic acid, glacial acetic acid, calcium aluminate and sodium chloride. Finally, saline solution $(\mathrm{NaCl}) 5 \%\left(50 \mathrm{~g} \mathrm{~L}^{-1}\right)$ at $25{ }^{\circ} \mathrm{C}$ was chosen due to its higher efficiency and low cost. Foams were immersed for 1 minute approximately. Later, they were subjected to mild drying $\left(24\right.$ hours at $\left.70{ }^{\circ} \mathrm{C}\right)$ in an oven. Change in color was observed: from black of the polyurethane foam to gray. A visual inspection allowed to control the uniform coating of samples.

Preparation of the slurry was the subject of a large number of trials. In order to avoid the collapse of the polyurethane mesh structure during the formation of the alumina-rutile $\left(\mathrm{Al}_{2} \mathrm{O}_{3}-\mathrm{TiO}_{2}\right)$ ceramic foam, some glassy phase-forming compounds were added. The amount of components to form glass was kept to be a minimum but enough for guaranteeing mechanical stability of the ceramic foam obtained. Thus, the formulation which allowed us to obtain the ceramic foams was: sodium feldspar (14\%), plastic clay or ball clay $(14 \%)$, reactive alumina $(25.5 \%)$, rutile $(5 \%)$, plus small percentages of gluten, boric acid, sodium silicate, sodium alginate, and sodium aluminate, in a total of $1.5 \%$. The water remaining content was $40.5 \%$. By this formulation, which allows percentage changes about $\pm 5 \%$ of each major component, ceramic foams made of mullite $\left(\mathrm{Al}_{6} \mathrm{Si}_{2} \mathrm{O}_{13}\right)$ and others compounds like aluminium titanate $\left(\mathrm{Al}_{2} \mathrm{TiO}_{5}\right)$ and glass-based binding phases related to $\mathrm{SiO}_{2}$ (phylosilicates) as starting materials ${ }^{14}$ can be obtained (Figure 1). It is important to remark the presence of wheat gluten below $1 \%$ in the slurry, acting as binder, that some authors replace it with ovalbumin, sucrose or other polysaccharides ${ }^{15}$.

The aqueous ceramic slurries were prepared by roll milling the components in the presence of spherical zirconia balls during 4 hours. Slurries with viscosity measured at a shear rate of $12.6 \mathrm{~s}^{-1}$ above $2.5 \mathrm{~Pa} \cdot \mathrm{s}$. Slurries with higher viscosity generally resulted in lower foam height and smaller cell size.

For priming the slurry on the cell polyurethane, first the slurry was placed in a bowl in water bath keeping stirred and heating slightly $\left(35-45^{\circ} \mathrm{C}\right)$. Then, the polyurethane samples, which were subjected to previously saline pre-priming, were immersed vigorously in the slurry. Afterwards, samples were left to drain one or two hours. The process was repeated in order to increase the thickness of the slurry layer settled on polyurethane.

Finally, with careful handling, samples were drained by gravity and also -where necessary- by applying compressed air. They were left to drain and air dry for several hours and then completely dried in an oven $\left(12\right.$ hours at $\left.70^{\circ} \mathrm{C}\right)$.

The ceramic replication process involves the substitution of cellular polyurethane by ceramic material, i.e., it forms a positive image of the sacrificed polyurethane. Then, the thermal process must be carefully scheduled to avoid the structural collapse of the foam. The sintering curve should be programmed with a focus on the first phase (from 370 to $420^{\circ} \mathrm{C}$ ), where hydrogencyanide $(\mathrm{CNH})$ is produced. In fact, as seen in some other works ${ }^{16}$, thermogravimetric weight loss study shows a three-stage decomposition for the cured polyurethane system by ending with a loss of carbonaceous residue at $\sim 630{ }^{\circ} \mathrm{C}$ in air.

For sintering the samples in laboratory a programmable electric oven Hobersal model PR400 in ambient air was used, with the following firing curve after some dilatometric tests: 1) rising slope up to $550{ }^{\circ} \mathrm{C}$ in 8 hours, 2) plateau at $550{ }^{\circ} \mathrm{C}$ for 1 hour, 3) rising slope up to $1200^{\circ} \mathrm{C}$ in 8 hours, 4) plateau at $1200^{\circ} \mathrm{C}$ for 1 hour, and 5) inertial free cooling in 8 hours, approximately.

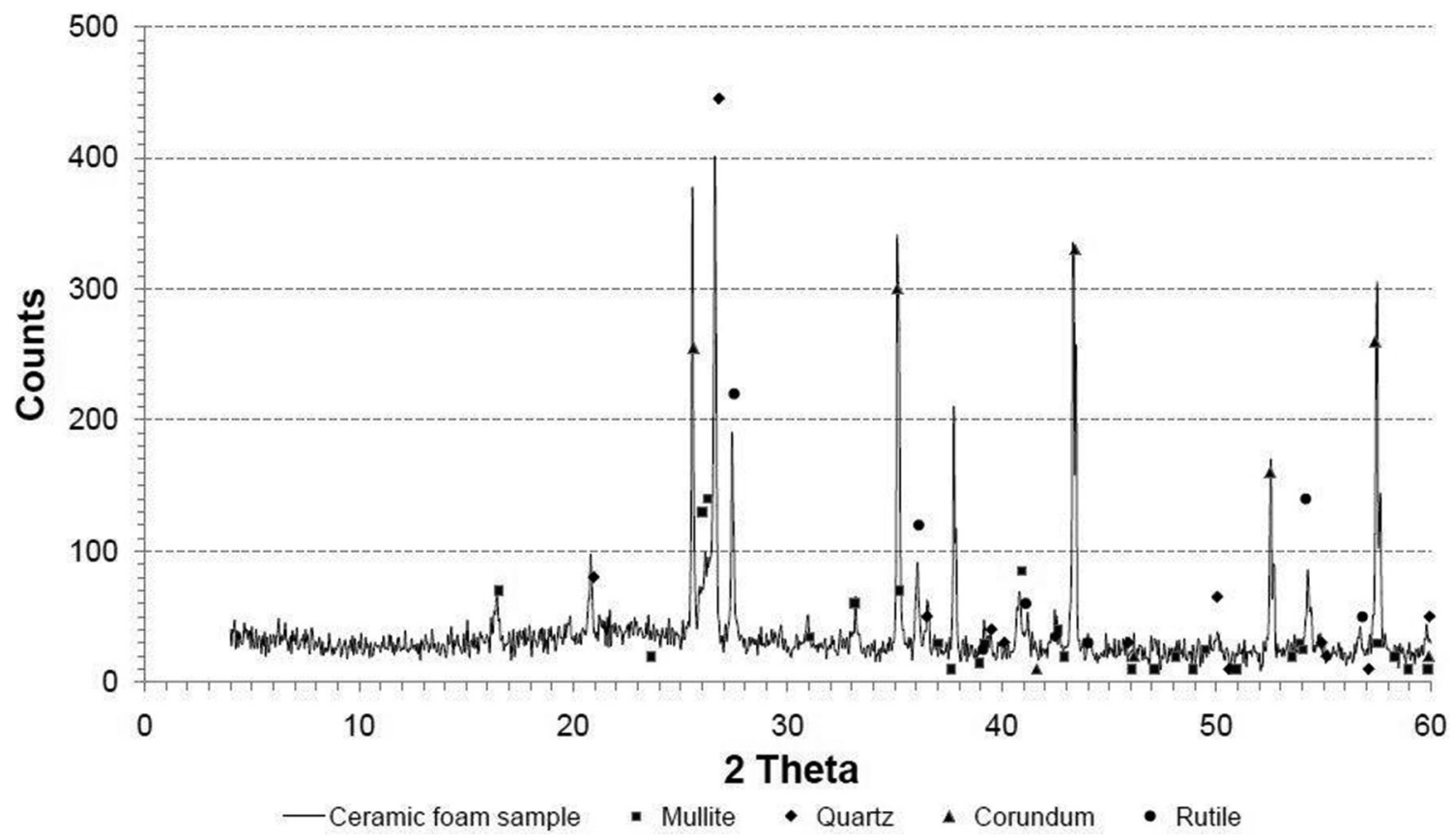

Figure 1. X-ray diffraction of the ceramic foam sample. Type $2 \mathrm{Th} / \mathrm{Th}$ locked. Start: $4.027^{\circ}$; end: $60.024^{\circ}$; step: $0.05^{\circ}$; step time: $3 \mathrm{~s}$. Major compounds presents are: Corundum $\left(\mathrm{Al}_{2} \mathrm{O}_{3}\right.$, rhombo.h.axes), 49.4\%; mullite ( $\mathrm{Al}_{6} \mathrm{Si}_{2} \mathrm{O}_{13}$, orthorhombic), 21.7\%; quartz ( $\mathrm{SiO}_{2}$, hexagonal), $19.4 \%$; and rutile $\left(\mathrm{TiO}_{2}\right.$, tetragonal), $9.5 \%$. 
Time spent in this thermal process (18 hours) is similar to that for cooking sanitary ceramic material (porcelain). The sintering maximum temperatures tested were 1000, 1200 and $1400{ }^{\circ} \mathrm{C}$. Finally, $1200^{\circ} \mathrm{C}$ was chosen for the ceramic foam with the composition described above as a balance between mechanical properties and energy costs. A higher temperature process would give higher mechanical resistance but would imply a substantial increase in manufacturing costs.

It is important to achieve a uniform temperature inside the oven to prevent the collapse of the polyurethane mesh. To do this, the samples were placed inside a parallelepipedic container made of refractory material. After sintering no remains of polyurethane are observed resulting a mesh with ellipsoidal shape cells where the average cell sizes range from 1000 to $2000 \mu \mathrm{m}$ (depending on the density of polyurethane precursor). The ceramic foams obtained are shown in Figure 2.

\section{Results and Discussion}

X-ray diffraction of sintered foam sample shows the presence of: alumina (corundum) (49.4\%), mullite (21.7\%), quartz (19.4\%), and rutile (9.5\%) (Figure 1).

Sintered samples were examined by confocal microscopy using a Sensofar Pl $\mu 2300$ equipment. Figure 3 shows a sample with a uniform texture in which dark islands are formed by mixed titania enrichment zones. No tialite phase $\left(\mathrm{Al}_{2} \mathrm{TiO}_{5}\right)$ has been observed, which is consistent with other studies, since it is not created below $1200^{\circ} \mathrm{C}^{[17]}$. Figure 4 shows a surface fault growing acicular crystals of mullite

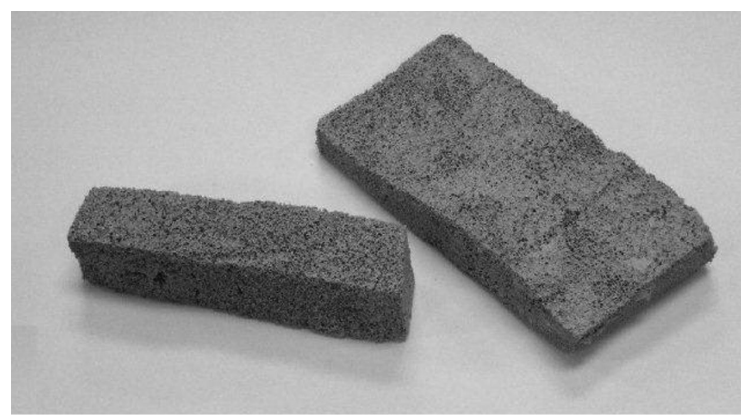

(a)

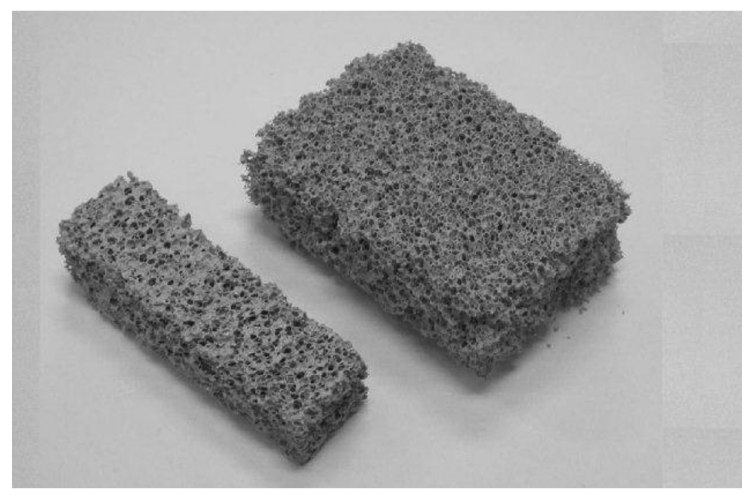

(b)

Figure 2. Samples of ceramic foams obtained for the two densities of polymers used as ceramic precursors: a) $1500 \mathrm{~kg} \mathrm{~m}^{-3}$; b) $1100 \mathrm{~kg} \mathrm{~m}^{-3}$.
$\left(\mathrm{Al}_{6} \mathrm{Si}_{2} \mathrm{O}_{13}\right)$ in a crack perpendicular to the surface. Figure 5 shows the surface of a sample with a rough texture of the surface caused mainly by the acicular growth of mullite and rutile enrichment areas.

These figures represent the interaction of the titania islands (dark) with the mullite surface that is homogeneous at all images, as was also noted by other authors ${ }^{18}$. No cracks and nor micropores have been observed. No tialite was detected. Tialite or aluminum titanate $\left(\mathrm{Al}_{2} \mathrm{TiO}_{5}\right)$ is a material obtained by sintering of stoichiometric oxides of aluminum and titanium at high temperature $\left(>1280{ }^{\circ} \mathrm{C}\right)^{14}$. At lower temperatures and cooling it spontaneously decomposes into its constituent oxides, this could be the reason why it is not listed in the product. Nevertheless, the ceramic foams obtained can be used in multiple applications both for their refractory properties and their low coefficient of expansion without discarding their intrinsic qualities for catalysis.

The resultant product is characterized by its ocher-yellow color that is maybe due to the presence of impurities in the raw materials used, as the mullite is white and the tialite is black. Bulk density ranged between 1100 and $1500 \mathrm{~kg} \mathrm{~m}^{-3}$

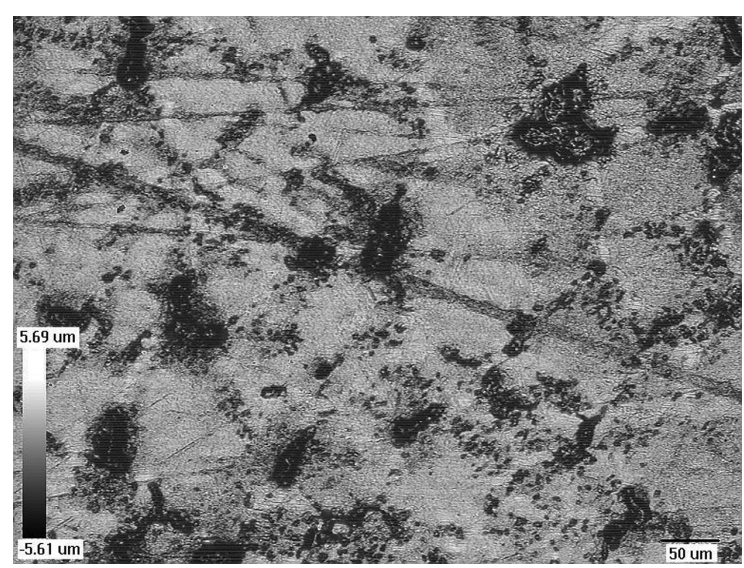

Figure 3. Confocal surface microscopic image showing the two phases present in ceramic foam: mullite (white) and alumina-rutile enrichment areas (black). Straight lines observed might be due to different thicknesses of material from the slurry during preparation or to irregularities in the sacrificial polymer template.

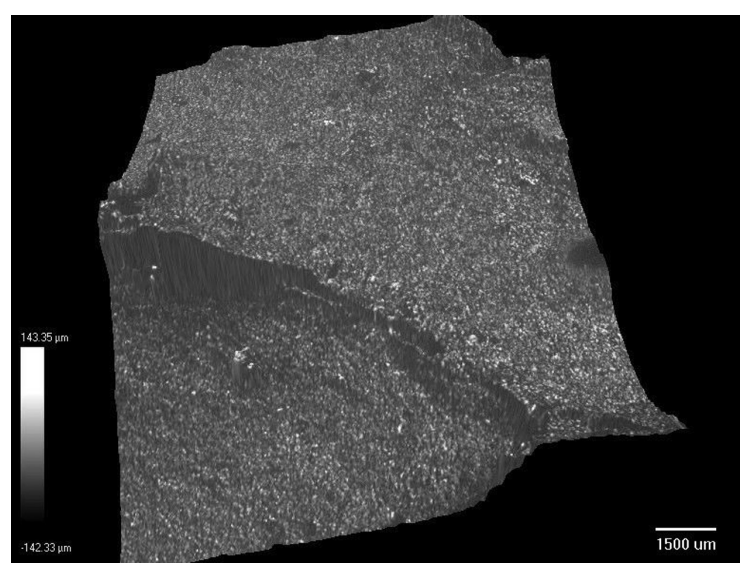

Figure 4. Morphology of acicular growth of mullite observed through confocal microscopy. 


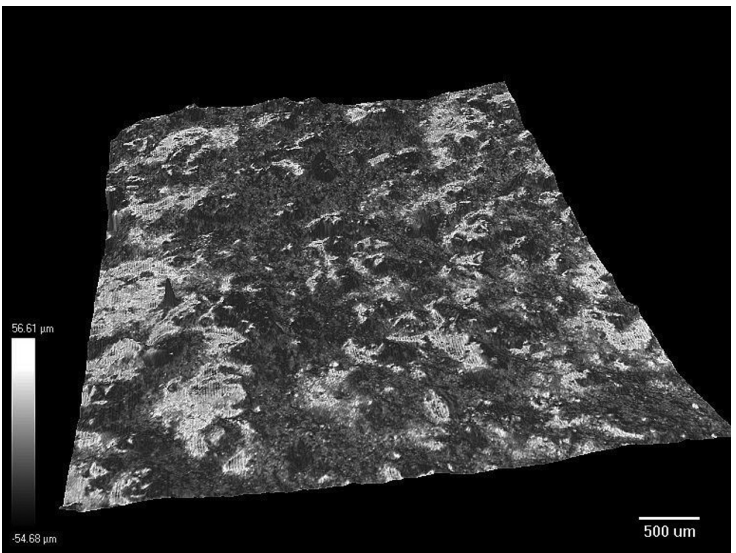

Figure 5. Texture of surface of the ceramic foam showing the distribution of segregated phases of oxides of aluminum and titanium (black) over mullite substrate (white).

depending on the density of polyurethane as well as on the thickness of the coating layer of slurry. Porosity is higher than $80 \%$. Elongated cells can be described as ellipsoids where the length of the longest axe is comprised betwen 1000 and $2000 \mu \mathrm{m}$. This is a morphological characteristic of open cells ${ }^{19}$.

If the excess of coating slurry is not removed, some macropores are closed by micrometer- thick membranes. These membranes provide improved mechanical strength of the product, but increase drop pressure in catalytic applications.

Compressive strength tests for determining the stress-strain curve were made using Instron Testmaster 2 equipment. The results are shown in Figure 6. Most mechanical (and other) properties decrease with increasing porosity $(0.8$ and $0.9 \mathrm{MPa}$ for 1.1 and $1.5 \mathrm{~g} \mathrm{~cm}^{-3}$, respectively; standard deviations of 0.05 and $0.07 \mathrm{MPa}$ ). Although the increase in porosity reduces the mechanical properties, other properties such as permeability and light-weightiness become specially interesting in these products. The denser material the greater tensile strength. This mechanical behavior is typical from materials which are locally brittle but strong as a whole. It was found that increasing the thickness of the slurry sticked to polyurethane, the mechanical strength had significantly increased, and this could be easily controlled. However, increasing the sintering temperature or subjecting the sample to a second sintering process did not increase its mechanical strength.

The largest contribution to the mechanical behavior seems to come from the mullite cristaline phase trapped between grains. This is expected since the compression strength of the ceramic foam is dependent upon the area within the structure that acts as load-bearing struts. A denser packing of ceramics particles around these areas helps to increase the effective load bearing area hence increasing the strength $^{20}$. The structure of the ceramic foam produced by this process of infiltration is limited by the structure of the polyurethane foam, and the process results in foams with poor mechanical properties due to the hollow struts ${ }^{15}$. In any case sufficient mechanical strength allows to fulfill all the requirements on application.

The porous characteristics of the product depend on: 1) composition of the particulated solutions, 2) maximum

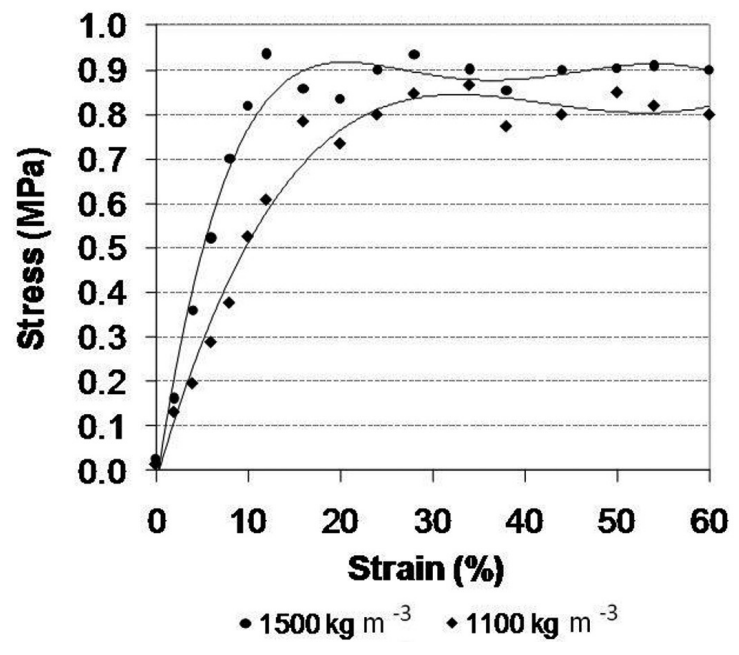

Figure 6. Stress-strain response curves of the two ceramic foams obtained. Standard deviations were $0.05 \mathrm{MPa}$ for the sample made with the foam of $1100 \mathrm{~kg} \mathrm{~m}^{-3}$ and $0.07 \mathrm{MPa}$ for the sample made with the foam of $1500 \mathrm{~kg} \mathrm{~m}^{-3}$.

temperature of sintering, and 3 ) heating rate (a fast rate can lead to collapse of micropores and finally to a closure of the mesh due to the formation of mullite). Shrinkage of the pore size, by measuring the sample with a caliper before and after sintering, is about $13 \%$ with respect to original polyurethane size, similar to the results reported by Tang et al. ${ }^{21}$.

The material is highly refractory up to at least $1600^{\circ} \mathrm{C}$, agreeing with Adler ${ }^{5}$, although at high temperatures the resistance to mechanical compression of this foam is expected to be low. The mullite microstructure creates a critical connecting link between process and properties. However, given the low content of mullite $(<30 \%)$, the coefficient of thermal expansion is not expected to be low, making the foam susceptible to thermal shock. But, the material has resistance against corrosion. Despite the overall simplicity of the technique the mechanical strength of cellular structures produced with this route can be substantially degraded by the formation of cracked struts during pyrolysis of the polymeric sponge. Then, the process has to be controlled, as suggested by Ogunwumi et al. ${ }^{22}$, increasing the formation of mullite.

The chemical resistance of the material was measured using three different solutions: $10 \% \mathrm{HNO}_{3}, 10 \% \mathrm{H}_{2} \mathrm{SO}_{4}$, and $10 \% \mathrm{NaOH}$. Samples were contacted with the acid solutions for up to 200 hours at room temperature and at $80^{\circ} \mathrm{C}$. Sample weight loss was measured before and after the acid etching using an analytical balance. The measured weight changes of several samples were averaged and resulted between 1.0 and $1.3 \%$ due mainly to impurities of raw materials and minor organic compounds destruction.

In relation to the microstructure, the resulting product obtained from sintering creates a flux of mullite $\left(\mathrm{Al}_{6} \mathrm{Si}_{2} \mathrm{O}_{13}\right)$ which crystallizes in an acicular morphology from which alumina-rutile enrichment phase $\left(\mathrm{Al}_{2} \mathrm{O}_{3}-\mathrm{TiO}_{2}\right)$ is segregated. Coatings remain intact under $1200{ }^{\circ} \mathrm{C}$ without stabilizers, in accordance with Mann et al. ${ }^{18}$. Mullite is a well-known ceramic material that has a tendency to form mixtures of 
equiaxed and acicular grains when heated above $1200^{\circ} \mathrm{C}$ as can be observed in Figure 4.

The three-phase alumina-rutile-mullite ceramic foam is characterized by good mechanical and thermal properties without observing random microporosity but high connectivity of macropores.

\section{Conclusions}

Open three-dimensional mesh structural ceramic foams with macropores (1000-2000 $\mu \mathrm{m})$, isotropic, uniform cell size distribution and a high degree of reticulation have been prepared from a commercially available polyurethane foam.

Its macro and microstructure and chemical composition suggest that this product might have high filtration efficiency, low pressure drop, fast regeneration, high thermal and chemical resistances, and high mechanical integrity. The microstructure studied by confocal microscopy consists of a rough surface with acicular growth of mullite and three mixed phases (alumina-rutile-mullite). It is possible that sintering processes at higher temperatures $\left(>1300^{\circ} \mathrm{C}\right)$ could provide a ceramic

\section{References}

1. Luyten J, Mullens S, Cooymans J, De Wilde A-M and Thijs I. New processing techniques of ceramic foams. Advanced Engineering Materials. 2003; 5(10):715-718. http://dx.doi. org/10.1002/adem.200300381.

2. Studart AR, Gonzenbach UT, Tervoort E and Gauckler LJ. Processing routes to macroporous ceramics: a review. Journal of the American Ceramic Society. 2006; 89(6):1771-1789. http:// dx.doi.org/10.1111/j.1551-2916.2006.01044.x.

3. Luyten J, Mullens S, Cooymans J, De Wilde AM, Thijs I and Kemps R. Different methods to synthesize ceramic foams. Journal of the European Ceramic Society. 2009; 29(5):829-832. http://dx.doi.org/10.1016/j.jeurceramsoc.2008.07.039.

4. Schwartzwalder K and Somers AV. Method of making porous ceramic articles. US Patent 3090094, 1963 May 21.

5. Adler J. Ceramic diesel particulate filters. International Journal of Applied Ceramic Technology. 2005; 2(6):429-439. http:// dx.doi.org/10.1111/j.1744-7402.2005.02044.x.

6. Pyzik AI and Li CC. New design of a ceramic filter for diesel emission control applications. International Journal of Applied Ceramic Technology. 2005; 2(6):440-451. http://dx.doi. org/10.1111/j.1744-7402.2005.02045.x.

7. Haugen H, Will J, Köhler A, Hopfner U, Aigner J and Wintermantel E. Ceramic TiO2-foams: characterization of a potential scaffold. Journal of the European Ceramic Society. 2004; 24(4):661-668. http://dx.doi.org/10.1016/S0955-2219(03)00255-3.

8. Muthasaran R and Apelian D. Filtration: a melt refining method. Journal of Metals. 1980; 32(9):14-18.

9. Khan PR, Su WM and Kim HS. The effect of various ceramic filters on the flow behavior, dross levels and fatigue properties of ductile iron. The British Foundryman. 1980; 80(5):237-244.

10. Mutharasan R, Apelian D and Romanowski CA. Laboratory investigations of aluminium filtration through deep-bed and ceramic open-pore filters. Journal of Metals. 1981; 33(12):1217.

11. Plesch G, Gorbar M, Vogt U, Jesenak K and Vargova M. Reticulated macroporous ceramic foam supported $\mathrm{TiO} 2$ for foam with the formation of mullite $\left(\mathrm{Al}_{6} \mathrm{Si}_{2} \mathrm{O}_{13}\right)$ and tialite $\left(\mathrm{Al}_{2} \mathrm{TiO}_{5}\right)$, but this has not been searched in this work.

By using polyurethane foams several parameters for controlling and tailoring useful characteristics of the ceramic material produced can be exploited, such as the pore size distribution and the surface area. Since it is possible to control microstructure, porosity and pore distribution, this ceramic foam can be tailored to meet requirements for deep bed filtration and/or fine particulate control. It also can be useful as a substrat for catalysts or scaffolds applications. However, further research should be carried out to suit it to a specific application.

\section{Acknowledgements}

This work was supported by Càtedra SEAT at ETSEIBUPC under contract in the frame of the MEDEA Project. The authors would like to thank Ms. Milena E. Gómez and Ms. Angela M. DeRosa for their help in the technical translation of this paper.

photocatalytic applications. Materials Letters. 2009; 63(34):461-463. http://dx.doi.org/10.1016/j.matlet.2008.11.008.

12. Studart AR, Gonzenbach UT, Tervoort E and Gauckler LJ. Processing routes to macroporous ceramics: a review. Journal of the American Ceramic Society. 2006; 89(6):1771-1789. http:// dx.doi.org/10.1111/j.1551-2916.2006.01044.x

13. Zhu X, Jiang D and Tan S. The control of slurry rheology in the processing of reticulated ceramic foams. Materials Research Bulletin. 2002; 37(3):541-553. http://dx.doi.org/10.1016/ S0025-5408(02)00674-8.

14. Sarkar N, Park JG, Mazumder S, Pokhrel A, Aneziris CG and Kim IJ. A2TiO5-mullite porous ceramics from particle stabilized wet foam. Ceramics International. 2015; 41(5):6306-6311. http://dx.doi.org/10.1016/j.ceramint.2015.01.056.

15. Dhara $\mathrm{S}$ and Bhargava P. A simple direct casting route to ceramic foams. Journal of the American Ceramic Society. 2003; 86(10):1645-1650. http://dx.doi.org/10.1111/j.1151-2916.2003. tb03534.x.

16. Peng HX, Fan Z, Evans JRG and Busfield JJC. Microstructure of ceramic foams. Journal of the European Ceramic Society. 2000; 20(7):807-813. http://dx.doi.org/10.1016/S0955-2219(99)00229-0.

17. Mann M, Shter GE and Grader GS. Morphological and phase composition changes during sintering of ultralight $\mathrm{Al} 2 \mathrm{O} 3 / \mathrm{TiO} 2$ foams. Journal of Materials Research. 2002; 4(17):831-837. http://dx.doi.org/10.1557/JMR.2002.0121.

18. Mann M, Shter GE and Grader GS. Effect of sintering on TiO2impregnated alumina foams. Journal of Materials Science. 2002; 37(19):4049-4055. http://dx.doi.org/10.1023/A:1020012931084.

19. Grosse J, Dietrich B, Incera G, Habisreuther P, Zarzalis N, Martin H, et al. Morphological characterization of ceramic sponges for applications in chemical engineering. Industrial \& Engineering Chemistry Research. 2009; 48(23):10395-10401. http://dx.doi.org/10.1021/ie900651c.

20. Muhamad Nor MAA, Hong LC, Arifin Ahmad Z and Md Akil H. Preparation and characterization of ceramic foam produced via polymeric foam replication method. Journal of Materials Processing Technology. 2008; 207(1-3):235-239. http://dx.doi. org/10.1016/j.jmatprotec.2007.12.099. 
21. Tang F, Fudouzi H, Uchikoshi T and Sakka Y. Preparation of porous materials with controlled pore size and porosity. Journal of the European Ceramic Society. 2004; 24(2):341-344. http:// dx.doi.org/10.1016/S0955-2219(03)00223-1.
22. Ogunwumi SB, Tepesch PD, Chapman T, Warren CJ, MeiscoetChauvel IM, Tennent DL. Aluminum titanate composition for diesel particulate filters. SAE Technical Paper. 2005; 2005-010583:1-7. 